\title{
Impact of Merchandize and Services Trade on Economic Growth of Pakistan
}

\author{
Muhammad Afzal \\ Department of Management Sciences, Preston University, Islamabad-Pakistan \\ Email: profafzal@gmail.com \\ Sheikh Shoaib Ahmed \\ Department of Economics, Preston University, Islamabad-Pakistan \\ Muhammad Waseem Shahzad \\ Department of Economics, Preston University, Islamabad-Pakistan
}

Received: 16 July 2019; Revised: 21 August 2019; Accepted: 4 September 2019; Published: 19 September 2019

\begin{abstract}
Trade comprises both merchandize and services trade. However, the former has over eclipsed the latter. Today services trade has also emerged an important component of international trade. Recent studies show that services trade is rapidly growing which assigns relative importance to services trade in developing economies. This study focused on Pakistan and empirically compared services and merchandise trade for the period 2001-2016. Model-I provided robust results. Merchandised trade has positive and significant impact on economic growth of Pakistan. Trade promotion not only depends on domestic economic conditions but also on favourable global economic scenario. Model-II estimation results are visibly different from that of Model-I. Services trade has negative impact on economic growth. Services exports have remained well below services imports that culminated in negative impact on economic growth. Pakistan policy makers may address the services trade seriously in order take care of adverse services trade balance that could be made possible by exploring weak areas of services exports with emphasis on innovation and information technology development.
\end{abstract}

Keywords: Merchandised trade, Services trade, Economic growth Pakistan

Jel Classification: F10

\section{Introduction}

International trade comprises visible and invisible trade. Visible trade (imports and exports of goods) is called Merchandize trade while services trade is known as invisible trade. Most of the trade research has focused and analyzed the merchandize trade and there is not significant research on services trade. Trade in services records the value of services exchanged between residents and non-residents of an economy, including services provided through foreign affiliates established abroad. Services include transport (both freight and passengers), travel, communications services (postal, telephone, satellite, etc.), construction, insurance, financial, computer and information services, royalties and license fees, cultural and recreational services etc. Trade in services drives the exchange of ideas, know-how and technology, although it is often restricted by barriers such as domestic regulations. The importance of trade in promoting economic growth and development in almost all countries particularly those which excel in exports is an open secret.

Exports of goods play an important role in value-addition of merchandise sector and hence enhance economic growth. Exporting goods has immense importance which may reduce average costs of production and can augment overall profitability and competitiveness among the firms (Ahmed, Hunjra, Iqbal, Khalil, 2014). On the other hand, services export has its own dynamic gains through knowledge and technological spillovers which have its own significance. Technology spillovers through trade in services have growth effect on the level of productivity (Neck, 2015).

According to Thomas (2016) trade in services brings technology spillovers in the scale economies which transform knowledge into productive assets. Likewise services exports may directly affect overall competitiveness and growth and indirectly affect employment, consumption and poverty. Moreover, increase in services exports may lessen the deficits in balance of payments. World Bank (2015) says that in most of the developing countries including Pakistan, the share of manufacturing sector has fallen sharply in GDP (gross 
domestic product) while the share of services has increased and now it contributes more than fifty percent to GDP. Merchandise value-added in Pakistan has fallen from 45 percent in 1960 to 24 percent in 2015 . This means that virtually the industrialized base of the country has lost ground not only to emerging markets, but also to services. Now the services trade is emerging as the fastest growing sector among all the sectors of Pakistan economy which accounts for around 58 percent of country's GDP, provide employment to one third population of the labor force. Now it is obvious that both the merchandise and services trade play important role in the determination of country's output and hence trade. However, it is desirable to look at the relative role of the two facets of trade and economic growth of an economy in order to arrive at sound macroeconomic policies.
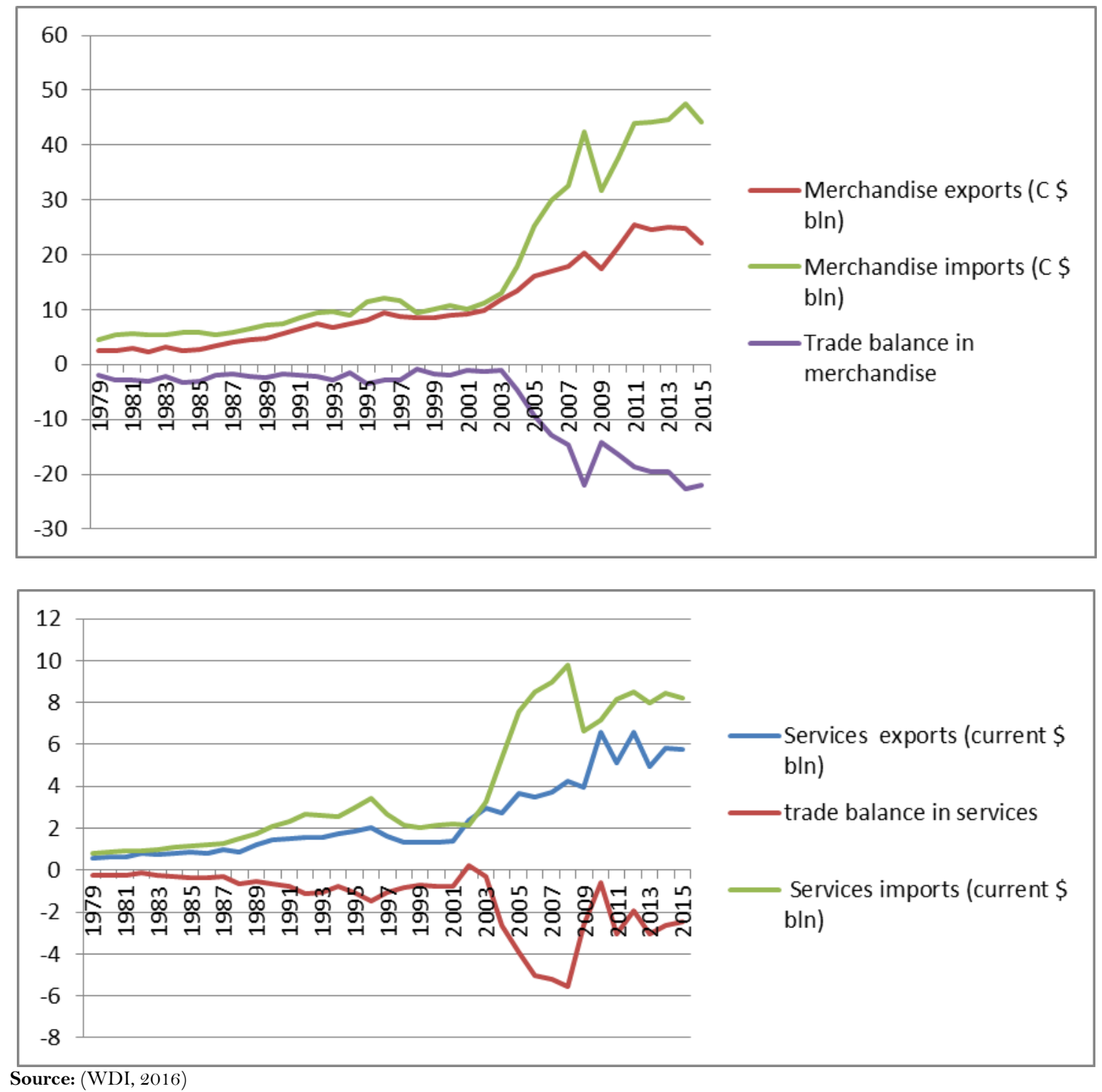

Figure 1 and 2 throw clear light on both trades and trade balance of Pakistan. The figures do not provide an optimistic picture.

\subsection{Significance of the Study}

Many studies have addressed and examined Pakistan trade scenario and have reported different results (Khan, Malik \& Hasan, 1995; Afzal 2004, Shirazi \& Manap, 2004; Aurangzeb, 2006; Afzal 2006, Umer 2014; Afzal \& Haider 2011; Afzal \& Hussain 2010). However, these and other studies have explored relative role of merchandize and services trade in Pakistan, which the present paper aims at to do using more recent data. This study is expected to provide policy implications to enhance the services trade. There is hardly any study 
which has comparatively analyzed the merchandise and services trade in Pakistan economy. This is also the motivation to undertake the current study. Therefore, the purpose of the paper is to examine empirically the impact of merchandise trade and services trade on economic growth of Pakistan.

\section{Literature Review}

It is widely believed that manufacturing industries have more growth inducing properties compared to other sectors of the economy because it leads to specialization in the production process, expand and distribute technology in the whole economy. Theoretical support of this hypothesis dates back to $19^{\text {th }}$ century.

The work of Kaldor $(1967,68)$ is the foremost example of the structural theory of economic growth which argued that manufacturing is the engine of growth. Ahmed, Butt, Alam and Kazmi (2000) examined the relationship between exports, economic growth and foreign debt for Bangladesh, India, Pakistan, Sri Lanka and four South East Asian countries using a trivariate causality framework. The study rejects the export-led growth hypothesis for all the countries, included in the sample, except Bangladesh. Kemal (2002) examined export-led hypothesis for five South Asian Countries including Pakistan. The study found no sign of causation in the short-run for Pakistan in either direction. Siddiqui, Zehra, Majeed, and Butt (2008) supported exportled growth hypothesis in Pakistan for the period 1971-2005 both in short-run as well as long-run. Thomas (2009) concluded that services have been the prime determinant of growth recovery in India since the 1990s.

Chakravarty and Mitra (2009) reported for India that manufacturing was visibly one of the determinants of overall growth in the economy, and services were also important for manufacturing growth. Timmer and deVries (2009) concluded that manufacturing contributed most in Latin America and Asia during normal growth period but in periods of acceleration, the services sector played the key role, though manufacturing continued to contribute positively to the growth of economy. Afzal and Rehman, (2008) empirically tested the export-led growth hypothesis for Pakistan and found that both short-run and long-run steady state exist among GDP and exports, while unidirectional causality exists between GDP and export that runs from GDP to export and supported the growth-driven exports hypothesis for the time period 1970- 2008.

Afzal and Ali (2008) concluded that an historical review of Pakistan's trade history demonstrated that economy had led exports more than the exports-led the economy. Economic growth responded to the emphasis on domestic market rather than on trade. Economic growth was vigorous in 1980 s but the rate of growth of exports was even less than the average annual export growth of 1970s. The slogan 'export-led growth' was adopted in 1990s. The slogan export-led growth coupled with extreme trade liberalization has seen imports immensely outstripping exports to open an alarming current account deficit in the 2000 s.

Afzal and Hussain (2010) using quarterly data $\left(1990 Q_{1}-2008 Q_{1}\right)$ and diverse quantitative techniques, examined the relationship between economic growth, exports and imports in Pakistan. Absence of long-run relationship between economic growth and exports and also between imports and economic growth was reported. The study found modest impact of exports on economic growth. This study did not find support for export-led growth hypothesis in Pakistan. Burger, Thissen, Oort, and Diodato (2014) investigated that the merchandise trade and services trade are mostly in depth product level. Secondly, they analyzed the domestic demand and production and the total exports and imports at the sector and product levels. They concluded that indirect and direct assessment of trade expenditure shows that the border effects of trade in services are generally high.

\subsection{Services Trade: Pakistan and Other Countries}

The focus of the earlier literature was on merchandise trade; however the most recent literature also emphasizes services trade. The evidence shows that services play a central role in developing human capital through education and skills. There is convincing evidence that higher services sector growth means accelerated economic growth (see Hoekman \& Eschenbach 2005; Arnold, Mattoo, \& Narciso, 2008). Mattoo, Rathindran and Subramanian, (2001) argued that modern services work best as transitional ideas become source of dispersion of information. Likewise, well planned financial services may lead to an effective addition to reserves for investment. Correspondingly, transportation services work as condition to contribute to trade and therefore, give rise to the effective circulation of goods inside and outdoor of the country.

Deardorff, (2005) analyzed the effect of services exports on services trade growth. He used input-tables of Austria for 1995, 2000 and 2003. It was found that the output multiplier for services improved from 1995 to 2000. It was also reported that the multiplier impact of services exports was larger than other components of final demand, since it tended to have more effect on national services. The available quantitative evidence suggests that policy reforms in the services sector can have major economic impacts. World Bank (2013), for 
example, uses a computable general equilibrium (CGE) model to show that the gains from reforming services sectors are reducing costs, markups, and trade penalties by 10 percent and each are at least four times as high as the gains from liberalization of goods trade. Using different data, Francois, Pindyuk, and Woerz (2009) concluded that a 50 percent reduction in services rates of protection produces income gains at least equivalent to those from elimination of tariffs affecting manufactured goods.

Eichengreen and Gupta (2009) argued that services as a whole show two distinctive waves in growth. The first wave of growth occurs in the traditional services (personal services) at the early stages in the development where the income level is low and the second wave occurs in the advance services (communication, technical, computer, business services) in the later stages of development process where income level is higher. The advance sector is more intensive in the use of sophisticated technology and so it acquires greater capacity for tradability across borders. Arnold, Javorcik, Lipscomb and Mattoo, (2010) reported a strong link between services sector and merchandise trade in Indian economy. The growth in banking, telecommunication, insurance and transport are a significant source of output growth and value addition in manufacturing industry.

It can be safely concluded from the literature, that services sector with rapid growth has positive effect on manufacturing sector and on overall economic growth. For example, well-organized transportation and efficient information and communications technology can encourage level of productivity across the whole economy. If the services sector is strong and modern sector, like business services etc then growth will be inclusive and vice versa.

Burger, et al. (2014) compared trade in goods and services and concluded that indirect and direct assessment of trade expenditure shows that the border effects for trade in services are generally high. Sandri, Alshyab and Abdullah (2016) analyzed empirically the growth share of the trade in goods and services in Jordan for the period 1980-2014. They reported that trade in goods had a negative effect on GDP in Jordan, whereas trade in services positively influenced economic performance. They concluded that an increase in trade in services by $1 \%$ increases output by $0.28 \%$ and strongly supported trade in services.

Thomas, (2016) observed the impact of services exports on India's economic growth, by evaluating the most recent legitimately available input-output table of India for 2007-08, with that of 1993-94. The study concluded that services trade will push Indian economy to achieve higher balance of payments equilibrium and also twin objective of economic growth and external stabilization simultaneously.

\section{Methodology and Data}

Generally it is believed that the trade has been largely associated with the merchandise trade although services have been increasingly traded over time. Today goods and services represent equally important components of world trade (World Trade Organization (WTO) 2015). Merchandise trade and services trade have their own characteristics. Most of the time both merchandise and services trade are interlinked as complements or substitutes of each other. Afzal (2004) says that the benevolent role of exports in economic growth and development attracted the attention of both economists and governments in LDCs in 1970 s after having experienced the problems of import-substitution industrialization (ISI) that developing countries including Pakistan pursued vigorously during 1950s and 1960. According to Thirlwall (2011) the export of goods is the main driver of trade for economic growth. Moreover, the effect of trade on growth is mitigated by the ability of developing countries to gain productivity growth through openness.

Over the past decades several studies investigated the exports-growth nexus. These studies confirmed a positive and significant relationship between exports and economic growth and suggested export promotion, trade liberalization and outward-looking strategy because of multidimensional favourable effects of exports (Afzal (2004).

Trade is normally associated with the merchandise trade though services trade has also assumed growing recognition and importance in recent years. Therefore, the relative impact of merchandise and services trade on economic growth is empirically examined by the following models in Pakistan:

$$
\begin{array}{ll}
\text { Model I: } & \mathrm{y}_{\mathrm{t}}=\alpha_{0}+\alpha_{1} \mathrm{~m}_{\mathrm{t}}+\alpha_{2} \mathrm{inv}_{\mathrm{t}}+\alpha_{3} \mathrm{er}+\alpha_{4} \mathrm{us}_{\mathrm{y}}+\mu_{\mathrm{t}} \\
\text { Model II: } & \mathrm{y}_{\mathrm{t}}=\beta_{0}+\beta_{1} \mathrm{~s}_{\mathrm{t}}+\beta_{2} \text { invt }+\beta_{3} \mathrm{er}+\beta_{4} \mathrm{us}_{\mathrm{y}}+\mu_{\mathrm{t}}
\end{array}
$$

Where

$\mathrm{t}=$ time period

$\mathrm{Y}=$ real gross domestic product $(\mathrm{GDP})$

$\mathrm{m}_{\mathrm{t}}=$ merchandise exports plus imports 
$\mathrm{s}_{\mathrm{t}}=$ services exports plus imports

er= nominal exchange rate

inv $=$ investment as \% of GDP

$\mathrm{us}_{\mathrm{y}}=$ United States income which is a proxy for World economic conditions

$\mu_{\mathrm{t}=}$ disturbance term that meets the classical regression assumptions

Model I and Model II deal with the impact of merchandise and services trade on the economic growth ( $\left.\mathrm{y}_{\mathrm{t}}\right)$ of Pakistan. Economic growth, represented by real GDP or real per capita GDP is influenced by a number of factors. However, in the international trade scenario, $\mathrm{Y}_{\mathrm{t}}$ is affected by trade in goods and trade in services $\left(\mathrm{m}_{\mathrm{t}}\right)$. Similarly $\left(\mathrm{Us}_{\mathrm{y}}\right)$ is used as a proxy for world economic conditions. This is an exogenous variable that can influence the economic growth in a multiplicity of ways as is evident from the various international events of crucial importance like globalisation etc (Afzal \& Dilshad 2018).

Exchange rate is also taken an explanatory variable because exchange rate plays not only an important role in the balance of payments but also in allocation of resources (Afzal \& Dilshad 2018). The depreciation of nominal exchange rate has positive impact on exports and hence on economic growth, because it is generally believed that depreciation has expected positive effects on the economy, though in many cases depreciation of exchange rate contribution to economic growth is not positive. Likewise investment is the most crucial variable that influences the growth of an economy. The Keynesian multiplier implies that a small change in investment will lead to a large increase in income level. This means that the investment is a vital factor of economic growth. It is difficult to anticipate exactly the expected sign of each coefficient.

Data Sources Data were obtained from the World development indicators (2017), State Bank of Pakistan Annual Reports, and International Financial Statistics (IFS). The period of the study is 2001-2016.

\section{Empirical Results}

Table-1.

Model 1: $\mathrm{y}_{\mathrm{t}}=\alpha_{0}+\alpha_{1} \mathrm{~m}_{\mathrm{t}}+\alpha_{2}$ inv $_{\mathrm{t}}+\alpha_{\mathrm{s}} \mathrm{er}+\alpha_{4} \mathrm{us}_{\mathrm{y}}+\mu_{\mathrm{t}}$

\begin{tabular}{|l|l|l|l|l|}
\hline Variable & Coefficient & Std. Error & t-Statistic & Prob. \\
\hline c & -79.11 & 29.96 & -2.64 & 0.0120 \\
\hline usy & 0.21 & 0.48 & 2.28 & 0.0360 \\
\hline er & 0.13 & 0.06 & 2.16 & 0.0290 \\
\hline inv & 0.10 & 0.04 & 2.38 & 0.0230 \\
\hline $\mathrm{R}^{2}$ & 4.12 & 1.26 & 3.26 & 0.0026 \\
\hline DW & 0.97 & - & - & - \\
\hline F-statistic & 1.93 & - & - & - \\
\hline
\end{tabular}

Table 1 shows the Model-I OLS results. $m_{t}$ ( merchandise exports plus imports) have positive and significant impact on economic growth $\left(\mathrm{y}_{\mathrm{t}}\right)$ and this suggests that 1 unit increase in merchandise trade will lead to 0.21 unit increase in GDP. The magnitude of the coefficient implies the vital role of imports and exports in the economic growth of Pakistan. Pakistan economy is desperately dependent on imports which are evident from the escalating trade deficit of the country since imports have far exceeded exports. Exports growth presents the most irritating scenario. Being negative for almost all years (2012-2018), except two, presents a depressing picture of foreign trade. This led to huge external debt and depreciation of the exchange rate (Government of Pakistan, 2017-18). US has positive and significant impact on the GDP. This implies that the increase in $\mathrm{US}_{\mathrm{y}}$ will increase the output in Pakistan through exports. This suggests favourable words World economic conditions will have beneficial impact on the economic growth particularly promotion of exports.

The coefficient for exchange rate is also positive and significant which means that depreciation of the exchange rate has expansionary effects on the economy. However, depreciation also has negative impacts because it makes "imports expensive, raises international debt burden and breeds inflation and reduces standard of living” (Afzal \& Dilshad, 2018). As expected investment is the most crucial factor influencing the economic growth because it has the largest coefficient that implies that one unit increase in investment will lead to more than four unit increase in economic growth and this is supported by the Keynesian multiplier 
effect. Durbin Watson is reasonable low and therefore autocorrelation does not pose a problem. F-statistic is also significant suggesting that all the regressors certainly impact the dependent variable.

\subsection{Model-II: Estimation Results}

Table-2.

OLS Results: Model-II: $\mathrm{y}_{\mathrm{t}}=\beta_{\mathrm{o}}+\beta_{1} \mathrm{~s}_{\mathrm{t}}+\beta_{2}$ inv $+\beta_{\mathrm{s}} \mathrm{er}+\beta_{4} \mathrm{us} \mathrm{s}_{\mathrm{y}}+\mu_{\mathrm{t}}$

Dependent Variable: Y (GDP)

\begin{tabular}{|l|l|l|l|l|}
\hline Variable & Coefficient & Std. Error & t-Statistic & Prob. \\
\hline $\mathrm{c}$ & 3.46 & 1.48 & 2.33 & 0.0265 \\
\hline $\mathrm{s}_{\mathrm{t}}$ & -0.03 & 0.06 & -1.85 & 0.5807 \\
\hline $\mathrm{us}_{\mathrm{y}}$ & -0.15 & 0.09 & -1.81 & 0.1168 \\
\hline $\mathrm{er}$ & -0.20 & 0.10 & -1.97 & 0.0574 \\
\hline inv & 0.52 & 0.12 & 4.32 & 0.0001 \\
\hline $\mathrm{R}^{2}$ & 0.96 & - & - & - \\
\hline $\mathrm{DW}$ & 1.90 & - & - & - \\
\hline F-statistic & 1538.91 & & & \\
& $(0.000)$ & & & \\
\hline
\end{tabular}

Estimation results of Model-II are visibly different from that of Model-I while only one regressor was changed. Services trade has negative and significant (10\% level of significant) impact on economic growth(y). 1 unit increase in Services (imports + exports) trade will lead to 0.03 unit decreases in GDP. Figure 2 ( WDI,2016) makes obvious that services exports have remained well below services imports particularly since 1980 s to the current decade resulting in adverse service trade balance that culminated in negative impact on economic growth. World economic conditions $\left(\mathrm{US}_{\mathrm{y}}\right)$ and exchange rate have also negative coefficients suggesting that when imports and exports of services is taken as an explanatory variable, the results are not positive. Only investment has expected positive and significant coefficient implying the most desirable role of investment in economic growth.

\section{Conclusions}

The importance of trade in promoting economic growth is universally acknowledged. Trade comprises both merchandize and services trade. However, the former has over eclipsed the latter. But today services trade has also emerged an important component of international trade. Majority of studies has addressed various aspects of merchandize trade. Recent studies concerning international trade show that services trade is rapidly growing which assigns relative importance to services trade in developing economies. This study focused on Pakistan and empirically compared services trade and merchandise trade in Pakistan. The study used two models that dealt with estimating the effect of merchandise and services trade on economic growth of Pakistan for the period 2001-2016.

Model-I provided robust results for the four explanatory variables (merchandised trade, US income, investment and exchange rate). Merchandise trade has positive and significant impact on economic growth of Pakistan implying the vital role of trade in economic growth. Positive and significant coefficient of US $\mathrm{S}_{\mathrm{y}}$ shows decisive function of the world economic a condition suggesting that trade promotion not only depends on domestic economic conditions but also on favourable global economic scenario. The largest coefficient of investment reveals investment as the most crucial factor influencing the economic growth.

Estimation results of Model-II are visibly different from that of Model-I. Services trade has negative impact on economic growth. Services exports have remained well below services imports that culminated in negative impact on economic growth. Except investment, World economic conditions $\left(\mathrm{US}_{\mathrm{y}}\right)$ and exchange rate have negative coefficients suggesting that Pakistan policy makers address the services trade seriously in order to take care of adverse services trade balance that could be made good by exploring weak areas of services exports with emphasis on innovation and information technology development.

\section{References}

Afzal,M. and Dilshad Ahmad (2018). Stabilization policies and domestic output response: Evidence from Pakistan. International Journal of Advanced and Applied Sciences, 5(4): 6-13. 
Afzal,M. (2004). Exports-economic growth nexus: Pakistan's experience. Indian Journal of Business and Economics, 3(2): 315-340.

Afzal, M. (2006). Causality between exports, world income and economic growth in Pakistan. International Economic Journal, 20(1): 63-77.

Afzal, M \& Karamat Ali (2008). An historical evaluation of export-led growth policy in Pakistan. Lahore Journal of Policy Studies, 2(1): 69-82.

Afzal, M., \& J. Haider, (2011). Estimation of import and export demand functions using bilateral trade data: The case of Pakistan. Foreign Trade Review, 66(2): 54-83.

Afzal, M., \& Ejaz Hussain, (2010). Export-led growth hypothesis: Evidence from Pakistan. Journal of Quantitative Economics, 8(1): 130-147.

Afzal, M., Rehman, H.,\& J.Rehman, (2008). Causal nexus between economic growth, export and external debt servicing: The case of Pakistan. Pakistan Economic and Social Review, 8(2): 315-340.

Ahmed, Q. M., Butt, M. S., Alam, S., \&Kazmi, A. A. (2000). Economic growth, export, and external debt causality: the case of asian countries. The Pakistan Development Review, pp: 591-6

Ahmed, M., Hunjra, A. I., Iqbal, M. K., \& Khalil, J. (2014).Impact of foreign direct investment, imports, exports of goods and services on economic growth of Pakistan. Bulletin of Business and Economics, 3(3): 155-16

Arnold, J. M., Mattoo, A., \& Narciso, G. (2008). Services inputs and firm productivity in Sub-Saharan Africa: Evidence from firm-level data. Journal of African Economies, 17(4): 578-599.

Aurangzeb (2006). Exports, productivity and economic growth in Pakistan: A time series analysis. The Lahore Journal of Economics, 11 (1): 01-18

Burger, M., Thissen, M., van Oort, F., \& Diodato, D. (2014). The magnitude and distance decay of trade in goods and services (No. TI 2014-031/VII).

Chakravarty, S., \& Mitra, A. (2009). Is industry still the engine of growth? An econometric study of the organized sector employment in India. Journal of Policy Modeling, 31(1): 22-35.

Eichengreen, and Gupta. P. (2009). The two waves of service sector growth. National Bureau of Economic Research, Working Paper No. 14968

Francois, J., O. Pindyuk, and J. Woerz. (2009). Trends in International Trade and FDI in Services. Discussion Paper: 200908-02.

Hoekman, B., and F. Eschenbach. 2005. Services policy reform and economic growth in transition economies, $1990-2004$. The World Bank Policy Research Working Paper No. 3663.

Kemal, A. R., (2002). Exports and economic growth in South Asia. A study prepared for the South Asia Network of Economic Research Institutes. Islamabad, Pakistan Institute of Development Economics.

Khan, A. H., A. Malik, and Hasan L. (1995). Exports, growth and causality: An application of cointegration and errorcorrection modeling. The Pakistan Development Review, 34: (4): 1003-1012.

Mattoo, A., Rathindran, R., \& Subramanian, A. (2006). Measuring services trade liberalization and its impact on economic growth: An illustration. Journal of Economic Integration, pp: 64-98.

Neck, Van M. (2015).The impact of exporting modern services on economic development.Journal of international Economics, 73 (2): 223-250.

Sandri, S., Alshyab, N., \& Ghazo, A. (2016). Trade in goods and services and its effect on economic growth-The Case of Jordan. Applied Econometrics and International Development, 16(2): 113-128.

Shirazi, N. S., Manap, T. A. (2004). Exports and economic growth nexus: The case of Pakistan. The Pakistan Development Review, pp: 563-581.

Siddiqui, S., Zehra, S., Majeed, S., \& Butt, M. S. (2008). Export-led growth hypothesis in Pakistan. The Pakistan Development Review, 31(3): 358-370.

Timmer, M. P., \& de Vries, G. J. (2009). Structural change and growth accelerations in Asia and Latin America: a new sectoral data set. Cliometrica, 3(2): 165-190.

Thirlwall, A. (2011). The balance of payments constraint as an explanation of international growth rate differences. PSL Quarterly Review, 64(259): 429-438

Thomas, M. P. (2016). Impact of services trade on India's economic growth and current account balance: evidence from post-reform period, New Delhi, Report No. 164.

Umer, F. (2014). Impact of trade openness on economic growth of Pakistan: an ARDL approach. Journal of Business $\mathbb{E}^{\circ}$ Economic Policy, 1(1): 2014.

World Bank (2.13, 2015 \&2016). World development indicators. Washington D.C.

World Trade Organization (2015). World Trade

https://www.wto.org/english/res e/statis e/its2015 e/its2015 e.pdf

Zaidi, A. (2005). Issues in Pakistan Economy. Karachi: Oxford University Press. 